Tér és Társadalom 2. évf. 1988/2.

108

\title{
MEGALAKULT AZ IPARI MINISZTÉRIUM REGIONÁLIS TUDOMÁNYOS TANÁCSA
}

1987. október 6-án az Iparpolitikai Tanács mellett müködó Regionális Tudományos Ta nács alakult az Ipari Minisztériumban.

A Tanács feladata - mint azt Kapolyi László ipari miniszter elmondta - az ipar regionális hatásainak, a különböző fejlesztések térségi-településhálózati feltételeinek tudományos elemzése, értékelése. Az egyes ágazatok fejlesztési terveinek területi-térségi következményeinek a vizsgálata mellett, tudományos szakvéleményt kell adnia a Tanácsnak az ipar szerkezet-átalakításának területi feltételeiról, illetve annak következményeiről. Összességében tehát az iparpolitika területi regionális vetületeinek elméleti összefüggéseinek megalapozása áll a testület tevékenységének középpontjában. A minisztérium által indított tudományos elemzéseket a Tanács megtárgyalja, ugyanakkor önállóan is kezdeményezhet kutatásokat és mindezek alapján javaslatokat dolgozhat ki a tárca számára az iparfejlesztést érin tô területi regionális kérdésekrơl.

A Regionális Tudományos Tanács elnöke Enyedi György akadémikus, résztvesznek munkájában az ipar területi kérdéseivel foglalkozó kutatók, tervezési és irányítási szakemberek. (Az MTA Regionális Kutatások Központját az elnökön kívül Barta Györgyi és Rechnitzer János képviseli.)

Az alakuló ülésen az ügyrend és szervezési kéndések megtárgyalása után, az MTA RKK Észak-dunántúli Osztálya által készített .Területi szempontok az ipar szerkezet-átalakításához" címü tanulmány vitájára került sor. (A TÉT egyik következó számában a tanulmányt és a vitán elhangzott észrevételeket közreadjuk.)

RECHNITZER JÁNOS 